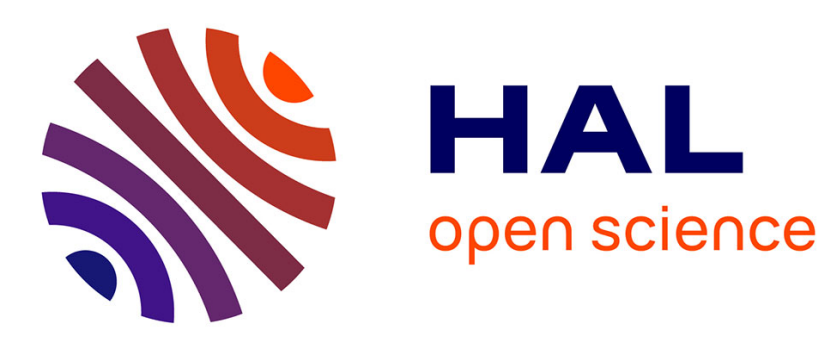

\title{
The delay-line voltage multiplier
}

\author{
G. Brautti, T. Clauser, A. Raino, V. Stagno
}

\section{To cite this version:}

G. Brautti, T. Clauser, A. Raino, V. Stagno. The delay-line voltage multiplier. Revue de Physique Appliquée, 1977, 12 (10), pp.1585-1585. 10.1051/rphysap:0197700120100158500 . jpa-00244374

\section{HAL Id: jpa-00244374 https://hal.science/jpa-00244374}

Submitted on 1 Jan 1977

HAL is a multi-disciplinary open access archive for the deposit and dissemination of scientific research documents, whether they are published or not. The documents may come from teaching and research institutions in France or abroad, or from public or private research centers.
L'archive ouverte pluridisciplinaire HAL, est destinée au dépôt et à la diffusion de documents scientifiques de niveau recherche, publiés ou non, émanant des établissements d'enseignement et de recherche français ou étrangers, des laboratoires publics ou privés. 


\title{
THE DELAY-LINE VOLTAGE MULTIPLIER
}

\author{
G. BRAUTTI, T. CLAUSER, A. RAINO and V. STAGNO \\ Istituto di Fisica and INFN, Bari, Italy
}

\begin{abstract}
Résumé. - On décrit un nouveau type de circuit pour produire des tensions élevées par multiplication de tension.

Abstract. - A new circuit for very high voltage production by voltage multiplication is described.
\end{abstract}

A new circuit for EHV production by voltage multiplication is now under test. The charging column is built to be electrically a band-pass delay line, whose discrete elements are tightly coupled resonant circuits. The capacitors are built in form of corona shields to allow good insulation with a very compact, selfsupporting structure. A large amount of RF energy can propagate along the structure from the ground side up to the HV head. One or two diodes per stage allow half-wave or full-wave rectification. A $40 \mathrm{kV}$ model has been tested in 1976, and a $300 \mathrm{kV}$ section is being built presently in our laboratory.

The advantages of the new structure are:

1) High current capability.
2) Low stored energy in the multiplier capacitors (less than $200 \mu \mathrm{J} / \mathrm{kV}$ at atmospheric pressure).

3) Large power available at the HV terminal, and at intermediate voltages for focusing, and pumping stations.

4) Easy transmission of signals to and from the head by a modulated carrier.

5) The structure is very compact, and does not waste additional room within the pressure tank, as compared with the parallel-fed Cockroft-Walton multiplier.

6) The structure allows the use of field shields at intermediate voltage for very high voltage generators. 